\title{
On science and subjectivity
}

\author{
ANGUS NICHOLLS
}

Robert J. Richards, The Romantic Conception of Life: Science and Philosophy in the Age of Goethe. Chicago, IL: University of Chicago Press, 2002. ISBN 0226712109 (hbk), 587 pp.

\section{INTRODUCTION}

Writing in 1882, towards the end of a long and distinguished career in the natural sciences, the famous German physiologist Emil Du Bois-Reymond (1818-96) passed a damning judgement regarding Johann Wolfgang Goethe (1749-1832) and his grasp of mainstream scientific methodology. Invoking the scientific trinity of empiricism, causality and mechanism, he observed:

Of this form of activity and the intellectual need that it presupposes and seeks to satisfy, Goethe obviously had no idea. He mentions mechanistic dissection only in order to reject it with hostility. In this way his theorizing restricts itself to allowing other phenomena to emerge out of a 'Primal Phenomenon' [Urphänomen] ... something like the way in which one hazy image follows another, without any plausible, causal connection. Goethe completely departed from the concept of mechanistic causality. For this reason his Theory of Colour remained, apart from its subjective parts, and despite the dedicated efforts of a long life, the stillborn fiddling of an autodidactic dilettante; for this reason he could never come to an understanding with the physicists; for this reason Newton's greatness was closed to him; and for this reason he saw, in the scientific optics of Young and Fresnel, only a 'cat's dinner' [Katzenpastete]. (Du Bois-Reymond, 1883: 29, my translation) 
This passage is only one example of the unhappy reception history suffered by Goethe's scientific magnum opus - the Farbenlebre or Theory of Colour - at the hands of mainstream science. Since Du Bois-Reymond made his judgement, many other eminent figures in German science have, at best, maintained a highly ambivalent attitude towards Goethe's efforts in the natural sciences. Following the widespread disenchantment with scientific modernity experienced in Germany during the first half of the 20th century and beyond, key figures like Werner Heisenberg and Carl Friedrich von Weizsäcker saw in Goethe's approach to the sciences a humanist countermodel to an excessively rationalist research culture. Goethe, according to this interpretation, is someone who can teach us something about the methodology, ethics, and dangers of science, while at the same time not being a 'real' scientist. As Weizsäcker wrote in his book Tragweite der Wissenschaft [The Consequences of Science] (1990):

We contemporary physicists are in our discipline students of Newton and not Goethe. But we know that this science is not absolute truth, but only a particular methodological procedure. We are forced to reflect upon the dangers and limits of this procedure. So we have cause to inquire, in Goethe's science, after that which is other than the prevailing science. (Weizsäcker, 1990: 457, my translation)

Working against this reception history, Robert J. Richards's The Romantic Conception of Life: Science and Philosophy in the Age of Goethe (2002) undertakes to rescue both Goethean science in particular, and German Romantic science in general, from its status as a non-rational, humanist critique hovering at the margins of genuine science. Richards, who is director of the Fishbein Center for the History of Science at the University of Chicago and the author of two books on Charles Darwin, has chosen wisely to steer clear of Goethe's often lambasted forays into optics and the theory of colour, focusing instead upon a more successful scientific hunting-ground for Goethe and his Romantic contemporaries: theories of biological development and morphology.

On the face of it, Richards's general claim that 'central currents of 19th century biology had their origins in the Romantic movement' (Richards, 2002: xix) may seem modest, even unsurprising. It has long been known, for example, that Goethe was one of the earliest theorists of morphology and comparative anatomy, having earned the distinction of discovering that an intermaxillary bone exists in the upper jaw of humans through comparisons made between human skulls and those of other vertebrates. On closer examination, however, Richards's book reveals itself to be important for two separate academic disciplines: literary criticism and the history of science. For German-speaking audiences in particular, the claim that Goethe was a 'Romantic' author and philosopher is highly provocative and contentious, 
and the case made by Richards in support of this hypothesis is both well argued and convincing. For historians of science, Richards's argument that Darwin's theory of natural selection was, through the mediation of Alexander von Humboldt, influenced by Romantic understandings of life developed by Schelling and Goethe among others, is at once bold, unorthodox and compelling.

In terms of his own research methodology, Richards adopts what might be called a 'Romantic' position with respect to his subject-matter. The primary 'objects' in question, in this case important texts in the history of late 18thand early 19th-century biology, are considered not simply in terms of their internal argumentation and conceptual rigour, but also in relation to both the cultural climate in which they were produced, and the individual psychologies, personal preoccupations and life-experiences of those who produced them. Here Richards reminds us that the natural sciences are also inescapably human sciences, if only in the limited sense that natural science can never free itself from the influence of human circumstances and emotions. In this way, the Romantic movement in Germany is seen by Richards as having been complementary to Enlightenment scientific methodology rather than exclusively opposed to it. The Romantics, he writes,

... were not uniformly opposed, as is usually assumed, to the Enlightenment emphasis on reason. Many of the Romantics might, rather, be classified as hyperbolically rational in that they believed the scientific mind could penetrate into all of the dark corners of the universe. (Richards, 2002: xvii)

Who, then, were these Romantics and how, according to Richards, did they influence the course of 19 th-century biology?

\section{ROMANTICISM}

The task of defining exactly what the Romantic movement was - who belonged to it, what its key dates are, what the term 'Romantic' actually means - has been laboured over by literary scholars and historians of ideas since the mid-19th century. The academic problems in the field are legion, since the Romantic movement swept across many European nations, and has justifiably been associated with a variety of aesthetic and ideological positions, ranging from progressive to reactionary. Scholarship on these issues has been divided between universalist approaches, which argue for a holistic, coherent Romantic movement spanning across several national literatures (a position famously adopted by M. H. Abrams and René Wellek), and particularist approaches, which argue that any attempt to assemble the many different 'Romanticisms' of Europe under one thematic or historical 
banner must inevitably fail (argued for, most notably, by A. O. Lovejoy in his essay 'On the Discrimination of Romanticisms'). Richards takes up an interesting strategy with regard to these problems. First, he confines himself by and large to discussions of Romanticism in Germany, which releases him from the task of synthesizing the German situation with Romantic currents in England, France and elsewhere. Secondly, his approach to German Romanticism diverges quite significantly from mainstream approaches to the Romantic period in German literary scholarship.

The traditional coordinates for German scholarship on Romanticism were set as early as 1833, with Heinrich Heine's eminently entertaining and ironic study Die romantische Schule [The Romantic School]. According to Heine, German Romanticism arose at the very close of the 18th century, in the university town of Jena, where the brothers Schlegel - August Wilhelm (1767-1845) and Karl Friedrich (1772-1829) - developed a program that called for an aesthetic revival of the Gothic middle ages that quickly descended into the dark mire of neo-Catholic obscurantism.

Heine's treatment of German Romanticism is significant both for its general characterization of the movement as aesthetically and politically conservative, and for the figures that it views as having stood outside the 'temple' of Romanticism: Goethe and Schiller. Concerning the aesthetic and political conservatism of early German Romanticism, Heine's judgement is correct insofar as the term romantisch initially conjured up, for the Schlegels, images of chivalric, mystical tales redolent of the medieval period. Moreover, following Napoleon's excursions into Prussia during 1806, Friedrich Schlegel eventually expressed an antipathy towards the French Revolution (which he originally supported), converting to Roman Catholicism and monarchism.

Matters become more complicated, however, when we consider the traditional German view that both Goethe and his long-time friend and aesthetic co-conspirator Friedrich Schiller (1759-1805) snubbed their noses completely at the perceived mysticism of German Romanticism. This myth, based upon Heine's discussion of Goethe and Schiller in The Romantic School, along with a few choice polemical statements made by Goethe against the pathological excesses of German Romanticism - the most famous of these being 'Classicism is the healthy, Romanticism is the sick' - led to Goethe and Schiller being sequestered off into their own aesthetic category: the serene world of Weimar Classicism, where clearer, more logical contours replaced the purported fogginess of all things 'Romantic'. There, as custodians of a national German culture chiselled in white marble, they would stay, or so at least would mainstream German literary history have us believe.

In reality, however, the history of Romanticism in Germany is more complex and interesting than this, and it is to Richards's credit that he brings to the fore these complexities and their broader implications for the influence of Romanticism on the history of biology. Richards challenges mainstream 
German literary history by placing both Goethe and Schiller alongside Friedrich Schlegel at the centre of German Romanticism, and the key to this repositioning exists in the respective responses of these three figures to the Critical Philosophy of Immanuel Kant (1724-1804). As Friedrich Schlegel was the figure who perhaps did more than any other to shape what the adjective 'Romantic' actually meant in late 18th- and early 19th-century Germany, his redefinition of that term under the influence of Kant is given central importance by Richards.

For Friedrich Schlegel, according to Richards, to 'be a Romantic was to think and act in a certain aesthetic and philosophical mode' (Richards, 2002: 199), a mode dictated by Kant's third Critique, the Kritik der Urteilskraft [Critique of Judgement] (1790). Kant's first Critique had shown that necessary, a priori conditions of human perception give us access to 'appearances' or phenomena while limiting our ability to make definitive statements concerning noumena or 'things in themselves', while the second Critique had demonstrated that reason could legislate freely over practical, moral actions. The task of the final Critique was to explore a third source of possible a priori principles: that of judgement. In Friedrich Schlegel's chief sphere of interest, that of aesthetics and artistic creation, Kant's conclusion in the third Critique was both exciting and highly suggestive: it is the apparent 'free play' of the imagination with the Understanding that allows us to make judgements as to the beauty of particular objects, since beauty itself cannot be defined in advance through concepts or laws. The imagination, moreover, also plays a highly active role in the production of artworks, in that 'Genius', according to Kant, does not simply reproduce given phenomena; rather, it is productive of its own laws while at the same time having no pre-given, rational conception of these laws or 'aesthetic ideas'.

As both radically undetermined and conceptually inexhaustible, Kant's aesthetic ideas of the imagination were appropriated by both Friedrich Schlegel and Schiller as the new engine of 'Romantic' poetry. For Friedrich Schlegel, Romantic poetry became 'progressive universal poetry' precisely because Kant had shown the human imagination to be infinite and inexhaustible; likewise Schiller, in his essay 'Über naive und sentimentalische Dichtung' ['On Naïve and Sentimental Poetry'] (1795), saw the role of the modern poet as being to progress continually toward the realization of an infinite, ethical ideal of human existence, a kind of future 'golden age', capable of perpetual transformation by reason and the imagination. Goethe, according to Richards, also went along for the ride, and in this connection he cites as evidence a remark made by Goethe in old age that 'Schiller demonstrated to me that I myself, against my will, was a Romantic' (Richards, 2002: 431). There is, however, little evidence of a consciously formulated and sustained program of Kantian aesthetics in Goethe's literary works; rather, the influence of Kant's third Critique is far more easily discernible in another of his 
fields of endeavour: namely, the theorization of biological development, to which we shall presently turn.

\section{ROMANTIC SCIENCE AND NATURPHILOSOPHIE [PHILOSOPHY OF NATURE]}

The influence of Kant's third Critique upon late 18th- and early 19th-century biology has been so well documented by historians of science that only a brief recapitulation is necessary here. Through investigating the works of earlier scientists such as Albrecht von Haller (1708-77), Charles Bonnet (1720-93) and Caspar Friedrich Wolff (1734-94), Kant became aware of a problem specific to the biological sciences: that of explaining the development and growth of organisms. Richards shows that while Haller and Bonnet favoured a Newtonian explanation, arguing that embryological development could be viewed as a purely 'mechanical unfolding and articulation of parts' (Richards, 2002: 213), Wolff saw fit to posit a non-mechanistic 'essential force' through which growth and development might be explained. Not surprisingly, any talk of mysterious 'essential forces' sent Kant's critical disposition into action, thereby producing the 'Critique of Teleological Judgement' - the scientific counterpart to the aesthetic component of the third Critique.

Like the scientific establishment of his day, Kant believed that the most plausible and acceptable explanations for natural occurrences are to be found in the cause-and-effect hypotheses offered by Newtonian mechanics. At the same time, Kant also thought that organisms and their constituent parts display such a high degree of organization, generative integration and reciprocity, that a teleology or design beyond simple cause-effect relationships is necessarily suggested to the scientific observer. Thus, just as the observation of some artworks produces aesthetic ideas like beauty, so too do certain features of organisms - like, for example, the growth of scales, fins and gills in fish - point towards an idea of the organism as a natural purpose or Naturzweck. The respective functions of scales, fins and gills in assisting a fish to swim can of course be accounted for easily through mechanistic explanations, but the idea of an organized being that generates parts with integrated, reciprocal relationships is, thought Kant, suggestive of a grander, teleological scheme at work in nature.

Science, according to Kant, is on firm ground when it posits mechanistic cause-effect relationships between the parts of organisms, since they conform to the laws of nature found in the a priori categories of the Understanding. When, on the other hand, it speculates as to the final ends or purposes of organisms and their parts, it is on much shakier ground, since such ends or purposes do not follow necessarily from the a priori categories; rather, they are reflective ideas formulated by the faculty of judgement - ideas which can 
play only a regulative, heuristic role in scientific methodology. Thus, for Kant, the scientist can proceed as if the scales, fins and gills of fish are organized according to an overarching teleology, or as if, in Richards's words, 'the very heart of nature beat out intrinsic patterns and pulsed with productive powers' (Richards, 2002: 67), but to assert that this is necessarily and objectively the case would be to overstep the limits of reason that Kant had delineated so carefully in the first and third Critiques.

The 'Romantics', as Richards presents them, were not the kind of people to observe limits - neither in their personal lives, nor in their scientific/philosophical endeavours. In this connection, an interesting sub-plot to the Romantic Conception of Life exists in the network of amorous relationships involving Caroline Böhmer Schlegel Schelling, whose lengthy surname maps the trajectory of a life containing three marriages. The highly intelligent and precocious Caroline kindled the desires of both Wilhelm and Friedrich Schlegel (she married the former after the death of her first husband, Georg Böhmer) before moving on to the young German philosopher, 12 years her junior, who would eventually shape Romantic ideas concerning biology perhaps more than any other, while also becoming Caroline's third husband: Friedrich Wilhelm Joseph Schelling (1775-1854). Richards maintains that recounting the complex personal connections between key figures in Jena Romanticism - particularly the circle involving Caroline, the brothers Schlegel, Goethe, Schiller and Schelling - is of more than mere historical/biographical value. Central to Richards's project is the idea that extensive crosspollination between the disciplines of biology, philosophy and literary criticism brought about a unique atmosphere in Jena, in which the idea of life could be theorized in a manner that fused scientific, philosophical and aesthetic elements into an organic whole. This fusion was - not unlike the various unions between Caroline and members of the Jena circle - also a transgression of limits, albeit limits of a Kantian variety rather than those of bourgeois propriety.

In response to Kant's proposition that teleological judgements concerning nature could have only a heuristic value, serving as hypothetical models that might help to direct scientific inquiry, Schelling responded with the view that our judgements concerning nature seem to match the development and patterns of nature itself, precisely because such judgements are themselves effects of nature. Schelling erected the philosophical framework behind this thesis in his Ideen zu einer Philosophie der Natur [Ideas for a Philosophy of Nature], published in 1797. Opposing the Kantian dualism of phenomena (objects as they are represented to human consciousness) and noumena (things or objects 'in themselves', independent of human subjectivity) Schelling argued that the human subject is not like an island, forever isolated from unmediated knowledge of the objects of nature. Rather, the human 'I' or self is understood by Schelling to have emerged from a greater, absolute 
subject, encompassing both the self and nature, which functions as the very condition of human consciousness. In this way the apparent parallelism between human thoughts about nature and nature itself could be explained, thought Schelling, by virtue of the fact that human consciousness is itself conditioned and determined by nature. Humans thus represent the highest level of development attainable in nature, in that human thoughts about the natural world are instances of nature engaging in acts of self-reflection, thereby embodying the central maxim of Schelling's early philosophical program: 'Nature should be mind made visible, mind the invisible Nature' (Schelling, 1988: 42).

This shift from a Kantian to a Schellingian understanding of the subject and its relationship to nature is most clearly demonstrated in Part Three of The Romantic Conception of Life, which contains Richards's eminently accessible account of Goethe's theory of biology. Although this section of the book often seems to overestimate the extent to which Goethe actually became a convert to Schelling's Naturphilosophie, a figure about whom Goethe often expressed significant reservations, it nevertheless renders obsolete other treatments in English of Goethe's morphological studies. Richards shows how Goethe's early work on botany grappled with an essentially Kantian problem: how can disparate, particular instances of plant life and plant development be understood within a universal, conceptual scheme? The putative answer to this question - Goethe's Urpflanze or 'primal plant', a universal model through which all plant development might be understood - was initially thought by its creator to exist in the external world, before becoming something akin to a Kantian teleological judgement. Richards's work on this stage of Goethe's scientific development is extremely significant for Goethe studies, since it shows, through analyses of various texts and notes written by Goethe on the Urpflanze, that he independently had formulated a neoKantian scientific methodology prior to being officially 'converted' to Kantianism by Schiller during the 1790s. As early as 1788, for example, Goethe already referred to the Urpflanze as a 'transcendental' model, based upon the form of the leaf, through which plant development could be theorized.

According to Richards, Goethe's early work on the Urpflanze laid the foundations for his later theory of morphology - a theory that extended into the fields of comparative anatomy and zoology, and which 'cleared the way for the triumph of Darwinian science' in the second half of the 19th century (Richards, 2002: 407). Richards argues that the key idea to emerge from Goethe's research into the Urpflanze was the general notion of developing archetypes or universal forms that could serve as generic theoretical models around which to organize research into various groups of species. Such archetypes would not only function as models for comparative analysis; rather, they could also, thought Goethe, be understood dynamically, as generative templates underlying the teleological development and growth of organisms, 
thereby providing a key to understanding the evolution of species. It is here where Goethe's and Schelling's movement beyond Kantian limits concerning teleological judgements becomes clear, as Richards observes:

After Kant, and especially because of the influence of Goethe and Schelling, biologists came to hold the teleological structure of nature not simply as if but as intrinsic: nature, whether in the individual or at large, really was purposively organized ... This meant that the teleological structuring of biological organisms modelled the conceptual structuring of the ideas in terms of which nature was understood. (Richards, 2002: 11)

The implications of such an understanding of nature for 19th-century biology were, according to Richards, enormous. No longer would nature be understood purely in Newtonian terms as a series of mechanical cause-effect relationships, and no longer would teleological ideas regarding nature remain confined within the rarefied Kantian realm of the 'as if'; rather, Richards demonstrates that eminent scientists like Johann Friedrich Blumenbach (1752-1840), Carl Friedrich Kielmeyer (1765-1844) and Johann Christian Reil (1759-1813) would all - at various stages of their careers, either independently or through the direct influence of Goethe and Schelling - come to adopt the view that nature is teleologically structured by something akin to an indwelling force, design or intellect which directs the development of organisms.

In this connection, Richards is wise to point out that while Schelling's Naturphilosophie influenced many 19th-century German biologists, this did not automatically render them all 'Romantic'. This is because Goethe and Schelling pressed the arguments of Kant's third Critique further than did biologists like Blumenbach, Kielmeyer and Reil, by arguing that science can be seen as an aesthetic undertaking in which the discerning of the indwelling archetypes of nature involves the same processes as those that occur in acts of aesthetic contemplation. According to this eminently Romantic worldview, the artist of genius is akin to the scientist, in that both are concerned with giving expression to the indwelling archetypes of nature, the former often unconsciously, the latter through a combination of empirical research, reflection and intuition. In the words of Friedrich Schlegel that appear as the epigraph to Richards's book, the Romantics held that 'All art should become science [i.e. Wissenschaft, meaning systematic knowledge in all academic disciplines] and all science art'. But was, as Richards suggests, Charles Darwin, the apparent epitome of British empiricism in the sciences, really influenced by this doctrine of science and art made one? And if so, is this influence significant enough to change the way in which we view Darwin's theory of natural selection? 


\section{ROMANTIC SCIENCE AND DARWIN}

In order to assess the most important and ambitious hypothesis of Richards's book - namely, that Charles Darwin (1809-82) was influenced by teleological conceptions of life similar to those advanced by Goethe and Schelling - it is necessary briefly to present the contrary (and, it must be said, mainstream) view, held by eminent theorists of evolution like Stephen Jay Gould and expressed in the following passage by Timothy Lenoir: 'In truth the works of Goethe and Darwin present us with two radically different conceptions of biological science' (Lenoir, 1987: 17). Lenoir argues that while Goethe's biology is undoubtedly teleological in its conception, Darwin's definitely is not. This is because the variations associated with Darwin's theory of natural selection occur spontaneously and by chance, regardless of any possible adaptive advantage, and not according to an overarching Bauplan or goaloriented process inherent in nature.

Richards sets out to challenge this view by describing broadly the cultural context in which Darwin composed the Origin of Species, paying particular attention to the ways in which yet another German - Alexander von Humboldt (1769-1859) - may have influenced its author. Humboldt moved in Jena intellectual circles during the 1790s, befriending Goethe and Schiller while also displaying an admiration for the Naturphilosophie of Schelling, before departing on a five-year voyage of scientific exploration to the Americas in 1799. Undertaking research in various scientific fields, including botany and zoology, he published a famous account of his journey, entitled Voyage aux régions équinoxiales du nouveau continent fait en 1799-1804 [Personal Narrative of Travels to the Equinoctial Regions of the New Continent, during the years 1799-1804]. The view of nature presented in this and other works by Humboldt is, according to Richards, heavily reminiscent of the aesthetic approach to nature undertaken by Goethe and Schelling.

Inspired by Humboldt's Personal Narrative, the young Darwin commenced his own voyage on the Beagle in 1831. Drawing on a number of heady passages from the Beagle Diary, Richards shows that the young Darwin's self-conception and mission as a scientist were inextricably bound up with his appreciation of Humboldt's project in the Personal Narrative a project in which nature was seen as a pulsating network of interrelated organisms, understood in simultaneously aesthetic and scientific terms. Of more importance, however, is Richards's contention that the Romantic theory of the archetype made its way into the work of Darwin, not only through the influence of Humboldt, but also via the mediation of two important English scientists: Joseph Henry Green (1791-1863) and his protégé Richard Owen (1804-92). German Romantic Naturphilosophen had influenced both figures; Green had read Schelling, while Owen was familiar with the work of two German anatomists, both of whom were, to varying 
degrees, followers of Schelling and Goethe: Lorenz Oken (1779-1851) and Carl Gustav Carus (1789-1869).

Green's notion of archetypes as essential forms, common to broad classes of botanical and zoological life, and recapitulated in more highly developed species, is suggestive of a pre-Darwinian theory of evolution. For his part, Owen also saw archetypes as essential forms common to groups of organisms, while at the same time repudiating any notion of naturalistic, genealogical evolution associated with recapitulation theory. Despite their differences, Richards argues that the scientific theories of both thinkers often teetered on the edge of pantheism, if not atheism. Perhaps frightened by the spiritual and professional consequences of holding to a completely naturalistic theory of evolution without any role played by a transcendent creator, both 'relocated archetypes in the Divine mind and regarded their appearance in nature as the result of God's creative activity' (Richards, 2002: 10).

Darwin, however, was not so cautious. Like Green, he held to the notion that archetypal structures are repeated at higher levels in the evolutionary chain. Unlike both Green and Owen, he also thought that such archetypal structures can be explained in a completely naturalistic way: that is, by virtue of common descent. For Darwin, however, these archetypes are not the same as the telic structures found in the Romantic Naturphilosophie of Schelling and his followers, since they are not intrinsic 'ideas' resident in organisms which determine and direct variations in species; rather, they are only secondary effects of what is normally understood to be a decidedly less metaphysical theory: that of natural selection. Richards's thesis that Darwin was influenced by a Romantic theory of archetypes that originally stemmed from Goethe and Schelling appears to be modest and substantiated, since nowhere is it claimed directly that Darwinian morphology is teleological in the Schellingian sense of the term. Instead, Darwin only used archetypes in order to substantiate his theory that certain variations in species are retained through natural selection.

The same cannot be said, however, in relation to Richards's treatment of Darwinian natural selection, expressed in the following passage:

Darwin never referred to or conceived natural selection as operating in a mechanical fashion, and the nature to which selection gave rise was perceived in its parts and in the whole as a teleologically self-organizing structure. (Richards, 2002: 534)

This argument is substantiated by quotations like this remarkable passage from the Origin of Species (1859):

It may be said that natural selection is daily and hourly scrutinizing, throughout the world, every variation, even the slightest; rejecting that which is bad, preserving and adding up that which is good; silently and 
insensibly working, whenever and wherever opportunity offers, at the improvement of each organic being in relation to its organic and inorganic conditions of life. (Darwin quoted in Richards, 2002: 534)

Offering a literal interpretation of these lines, Richards cites them as direct evidence of Darwin's adherence to a teleological theory of nature, conceived in the spirit of German Romantic Naturphilosophie. He detects a Romantic element in the moral tones of this and similar passages by Darwin, which present nature as an integrated system working for the common good of its organisms. Seen in this light, Darwinian archetypes - while remaining expressions of common descent across species, and while not amounting in and of themselves to telic structures - come to be seen as secondary expressions of an 'intellect' or teleology resident in the natural world. This idea of nature comes through more clearly still in Darwin's 'Essay of 1844'. Comparing the processes of artificial selection used by animal breeders to those of natural selection, he writes:

Let us now suppose a being with penetration sufficient to perceive differences in the outer and innermost organization quite imperceptible to man, and with forethought extending over future centuries ... we assume his discrimination, and his forethought, and his steadiness of object, to be incomparably greater than those qualities in man, so we may suppose the beauty and complications of the adaptations of the new races and their differences from the original stock to be greater than the domestic races produced by man's agency. (Darwin quoted in Richards, 2002: 536)

Do these passages prove that Darwin's theory of natural selection was aesthetic and teleological? At the very least they suggest that from its initial conceptualization in essays of the early 1840s, to its final appearance in the Origin of Species in 1859, Darwin was given to thinking of natural selection in poetic, metaphorical terms which are suggestive of a teleology at work in nature, while also being redolent of Alexander von Humboldt's influence. Sceptics, however, may wish to argue that these passages are merely examples of Kantian teleological judgements. Even if Darwin's early theory of natural selection was, in the words of Richards, 'cast in the image of a divine Being' (Richards, 2002: 536), was this divine Being something that Darwin actually believed in and sought scientifically to prove? Or was it merely a metaphor used to communicate a novel scientific idea? These difficult questions, which ultimately relate to authorial intention, are not answered by Richards, and nor should we expect them to be. Although Richards's chapter on Darwin is rather brief, and is argued in far less detail than the earlier sections on Schelling and Goethe, it nevertheless provides a fascinating alternative image of Darwin as a poetically charged scientist who was heavily influenced by, 
and perhaps even in the final analysis an adherent to, teleological conceptions of biology.

\section{CONCLUSION: ROMANTICISM AND THE RELATIONSHIP BETWEEN THE HUMAN AND NATURAL SCIENCES}

In his 1953 essay 'Wabrheit in den Geisteswissenschaften' ['Truth in the Human Sciences'], the German philosopher Hans-Georg Gadamer (1900-2002) addresses the relationship between the Geisteswissenschaften (a term encompassing both the humanities and the social sciences) and the Naturwissenschaften (the natural sciences). Discussing the historical period dealt with by Richards in The Romantic Conception of Life, Gadamer observes that the epoch of Romanticism and German Idealism was important precisely because it yielded 'knowledge which is alive on the borders of the Enlightenment and method in science' (Gadamer, 1994a: 26). What is this knowledge and what significance does it have for contemporary research? Gadamer answers these questions by arguing that while the natural sciences have undoubtedly surpassed the human sciences in terms of method, empirical verifiability and the control of nature, 'they do not encompass ... that which is most worth knowing, namely the final purposes that all control of nature and human beings must serve' (Gadamer, 1994a: 26).

Robert J. Richards shows that philosophers and scientists in the Age of Goethe often saw themselves as engaged in research that might have led, not to a purely amoral 'control of nature', but rather to an appreciation of the role to be played by humans within a teleological network of organisms, understood in both aesthetic and moral terms. This simultaneously philosophical and scientific program, first suggested by the parallel aesthetic and scientific components of Kant's third Critique, was pursued by the likes of Goethe and Schelling during the late 18th and early 19th centuries, while also continuing, at least in muted form, in certain passages written by Darwin concerning natural selection. While Goethe's aesthetic approach to nature and Schelling's ambitious hypothesis that natural objects develop according to teleological 'ideas' resident in nature have long been superseded in the biological sciences, the scientific legacies of both thinkers nevertheless retain an importance for researchers today.

The influence of Schelling, in particular, upon modern understandings of subjectivity has been given insufficient attention in English-language scholarship. Richards shows that Schelling, through his attempts to understand the relationship between human subjectivity and the objects of nature, eventually arrived at a model of the subject in which natural processes infiltrate and determine human thinking at every level. This model rendered the Enlightenment 
ideal of completely objective, dispassionate analysis of natural objects problematic, since it showed that human thinking about nature could never become fully transparent to itself. Schelling's understanding of the subject would also become extremely important for later theorists of the unconscious, particularly Carl Gustav Carus and Eduard von Hartmann (1842-1906), an importance recognized by Julia Kristeva in her observation that 'One cannot hope to understand Freud's contribution, in the specific field of psychiatry, outside of its Romantic filiation' (Kristeva, 1991: 181). In this connection, anyone interested in the influence exerted by German Idealism and Romantic Naturphilosophie upon the history of psychoanalysis should read Odo Marquard's study: Transzendentaler Idealismus, Romantische Naturphilosophie, Psychoanalyse [Transcendental Idealism, Romantic Philosophy of Nature, Psychoanalysis] (1987), as yet untranslated.

Richards's study is also largely successful in improving Goethe's scientific standing, demonstrating quite clearly that Goethe's notion of biological archetypes was important for 19th-century biology, while perhaps also having a residual influence upon Darwin. But in focusing closely upon Goethe's biological research and his affinities with the Naturphilosophie Schelling, Richards sometimes neglects to communicate Goethe's extremely prescient understanding of what might be called the 'scientific unconscious': the tendency of science - through a combination of what he called 'impatience; haste; self-satisfaction; rigidity; formalistic thought; prejudice; ease; frivolity; fickleness' - to undertake research for dubious ends, with insufficient insight into its deepest desires and motives (Goethe, 1994a: 14). Goethe's only antidote to these eminently human shortcomings was to emphasize repeatedly the duty of the scientist to engage in self-reflection, and, when in doubt, to return again and again to the objects of nature (Goethe, 1994b: 33). It is precisely in this sense that Gadamer observes that Goethe, especially after Schiller's death and unlike many of his German Idealist contemporaries, 'had no intention of interceding in favour of the intellectual intuition of later Idealism', and instead believed 'more in nature than in freedom' (Gadamer, 1994b: 13).

Notwithstanding this very minor shortcoming, Richards's book is both 'Goethean' and 'Gadamerian' in the very best senses, in that it brings to light the necessary limits placed upon all science by the forces of subjectivity, culture and history. There is, in fact, no other extant work in English that explicates the complex interrelationships between philosophy, literature, aesthetics and scientific research in German Romanticism as clearly, entertainingly, accessibly and comprehensively as The Romantic Conception of Life. 


\section{NOTE}

This publication was prepared with the support of the Claussen-Simon Foundation.

\section{BIBLIOGRAPHY}

Abrams, M. H. (1971) Natural Supernaturalism: Tradition and Revolution in Romantic Literature. New York: Norton.

Du Bois-Reymond, E. (1883) Goethe und kein Ende [Goethe and No End]. Leipzig: Verlag von Veit.

Gadamer, H.-G. (1994a) 'Truth in the Human Sciences', in B. R. Wachterhauser (ed. and trans.) Hermeneutics and Truth. Evanston, IL: Northwestern University Press, pp. 25-32.

Gadamer, H.-G. (1994b) 'Goethe and Philosophy', in R. H. Paslick (ed. and trans.) Hans-Georg Gadamer: Literature and Philosophy in Dialogue. Albany, NY: State University of New York Press, pp. 2-19.

Goethe, J. W. (1994a) 'The Experiment as Mediator Between Object and Subject', in D. Miller (ed. and trans.) Goethe: The Collected Works, Volume 12, Scientific Studies. Princeton, NJ: Princeton University Press, pp. 11-17.

Goethe, J. W. (1994b) 'Doubt and Resignation', in D. Miller (ed. and trans.) Goethe: The Collected Works, Volume 12, Scientific Studies. Princeton, NJ: Princeton University Press, pp. 33-4.

Gould, S. J. (1977) Ever Since Darwin. New York: Norton.

Heine, H. (1968) The Romantic School and Other Essays, ed. and trans. J. Hermand and R. C. Holub. New York: Continuum.

Kristeva, J. (1991) Strangers to Ourselves, trans. L. S. Roudiez. New York: Harvester Wheatsheaf.

Lenoir, T. (1982) The Strategy of Life: Teleology and Mechanics in NineteenthCentury German Biology. Dordrecht: D. Reidel.

Lenoir, T. (1987) 'The Eternal Laws of Form: Morphotypes and the Conditions of Existence in Goethe's Biological Thought', in F. Amrine, F. J. Zucker and H. Wheeler (eds) Goethe and the Sciences: a Reappraisal. Dordrecht: D. Reidel, pp. 17-28.

Lovejoy, A. O. (1924) 'On the Discrimination of Romanticisms', Publications of the Modern Language Association (PMLA) 39: 229-53.

Marquard, O. (1987) Transzendentaler Idealismus, Romantische Naturphilosophie, Psychoanalyse [Transcendental Idealism, Romantic Philosophy of Nature, Psychoanalysis]. Cologne: Verlag für Philosophie Jürgen Dinter.

Richards, R. J. (1987) Darwin and the Emergence of Evolutionary Theories of Mind and Behaviour. Chicago, IL: University of Chicago Press.

Richards, R. J. (1992) The Meaning of Evolution: The Morphological Construction and Ideological Reconstruction of Darwin's Theory. Chicago, IL: University of Chicago Press.

Richards, R. J. (2002) The Romantic Conception of Life: Science and Philosophy in the Age of Goethe. Chicago, IL: University of Chicago Press. 
Schelling, F. W. J. (1988) Ideas for a Philosophy of Nature, trans. E. E. Harris and P. Heath. Cambridge: Cambridge University Press.

Weizsäcker, C. F. (1990) Tragweite der Wissenschaft [The Consequences of Science]. Stüttgart: Hirzel.

Wellek, R. (1963) Concepts of Criticism. New Haven, CT: Yale University Press.

\section{BIOGRAPHICAL NOTE}

ANGUS NICHOLLS is the Claussen-Simon Foundation research lecturer in German and Comparative Literature in the Institute of Germanic and Romance Studies, School of Advanced Study, University of London.

Address: Institute of Germanic Studies and Romance Studies, School of Advanced Study, 29 Russell Square, London WC1B 5DP. Tel: (+44) (0) 207 862 8964. Fax: (+44) (0) 207862 8970. [email: angus.nicholls@sas.ac.uk] 